\title{
Genetic and environmental effects on semen traits in Lacaune and Manech tête rousse AI rams
} (Open Access publication)

\author{
Ingrid DAVID $^{\mathrm{a} *}$, Xavier DRUART ${ }^{\mathrm{b}}$, Gilles LAGRIFFOUL ${ }^{\mathrm{c}}$, Eduardo \\ MANFREDI $^{\mathrm{a}}$, Christèle ROBERT-GRANIÉ ${ }^{\mathrm{a}}$, Loys BODIN ${ }^{\mathrm{a}}$ \\ a Station d'amélioration génétique des animaux, INRA, UR631, BP 52627, \\ 31320 Castanet-Tolosan Cedex, France \\ ${ }^{b}$ Physiologie de la reproduction et des comportements, INRA - CNRS UMR1291, \\ 37380 Nouzilly, France \\ ${ }^{\mathrm{c}}$ Institut de l'Élevage, ANIO, BP 42118, 31320 Castanet-Tolosan Cedex, France
}

(Received 4 May 2006; accepted 22 February 2007)

\begin{abstract}
Data from 51107 and 11839 ejaculates collected on rams of the "Lacaune" and "Manech tête rousse" breeds, respectively, were analysed to determine environmental and genetic factors affecting semen production traits (ejaculate volume, semen concentration, number of spermatozoa and motility) in young ( $\leqslant 1$ year) and adult ( $\geqslant 2$ years) rams. Fixed effects and variance components were estimated using multiple trait animal models within each breed. For all traits, the main environmental effects identified were year, season, number of ejaculations, daily variation, interval from previous to current collection and age. Heritability estimates were moderate for volume, concentration and number of spermatozoa (0.12 to 0.33$)$ and lower for motility ( 0.02 to 0.14$)$. Genetic correlations between ages differed from 1 for all traits $(0.14$ to 0.90), indicating that semen characteristics corresponded to different traits in young and adult rams. Genetic and phenotypic correlations among traits within age category were globally similar for the different breeds and categories of animals.
\end{abstract}

$\mathrm{ram}$ / semen / environmental factor

\section{INTRODUCTION}

In the ovine species, more than 800000 artificial inseminations (AI) are performed each year in France with fresh semen. The insemination technique is used during a limited period of the year, therefore semen production units

${ }^{*}$ Corresponding author: Ingrid.David@ @oulouse.inra.fr 
need to produce a large amount of useful semen per day with a limited number of rams. For a given preservation technique, the number of doses produced per ejaculate depends on the volume, sperm concentration and sperm motility. These traits are affected by environmental, management, physiological status and genetic effects. The principal environmental effects reported in the literature are the age of the ram, season or photoperiodic treatment, nutrition, rhythm of collection, collector and daily period [2, 4, 6, 8, 12, 15, 17, 21-23]. A wide range of genetic parameter estimates of semen traits have been reported in the literature but limited data are available for sheep [7,22].

In order to improve their efficiency, French AI centres are interested in (1) the identification of the main environmental effects affecting semen production (volume, concentration, number of spermatozoa and motility); (2) estimation of the corresponding genetic parameters; and (3) prediction of adult ( $\geqslant 2$ years) semen production based on early production in young rams ( $\leqslant 1$ year). To cover these requirements, a study was performed on semen production traits in both adult and young rams. This paper presents the results obtained on two sets of similar data recorded at two AI centres with different breeds: Lacaune and Manech tête rousse.

\section{MATERIALS AND METHODS}

\subsection{Data}

Routine recorded semen production data were provided by two AI centre members of the ANIO (association nationale des centres d'insémination ovine). Data were collected from "Lacaune" (LAC) rams during the years 1996-2004 and "Manech tête rousse" (MTR) rams during the years 2000-2004. Each breed was housed in a separate AI centre located in the southwest of France: Aveyron (LAC) and Pyrénées Atlantiques (MTR). Rams were involved in a dairy selection scheme and belonged to two categories: young rams under progeny testing and proven adult rams. Only records of ejaculates corresponding to the intensive period of ram collection (May to August), after photoperiodic treatment in one centre or a melatonin implant in the other, were used for the analysis. In total, 51107 and 11839 ejaculates of LAC and MTR rams were analysed, respectively. Data were collected over a 1 to 5 year period depending on the rams. The interval between collections within year varied from 1 to 28 days. Detailed data descriptions are presented in Table I.

All ejaculates were obtained after natural ejaculation in an artificial vagina by the same team of collectors during the entire period. For a given ram the 
Table I. Description of data recorded in AI centres.

\begin{tabular}{|c|c|c|c|c|}
\hline & \multicolumn{2}{|c|}{ Center 1} & \multicolumn{2}{|c|}{ Center 2} \\
\hline & Adult & Young & Adult & Young \\
\hline Volume* $(\mathrm{mL})$ & $0.96(0.32)$ & $0.67(0.23)$ & $1.05(0.32)$ & $0.58(0.26)$ \\
\hline Concentration $*\left(\times 10^{6} \mathrm{spz} \cdot \mathrm{mL}^{-1}\right)$ & $3.52(0.69)$ & $3.33(0.74)$ & $4.50(0.80)$ & $4.10(0.90)$ \\
\hline Number of spermatozoa* & $3.41(1.29)$ & $2.26(0.97)$ & $4.80(1.70)$ & $2.50(1.30)$ \\
\hline Motility* & $4.70(0.10)$ & $4.64(0.12)$ & $4.70(0.20)$ & $4.60(0.30)$ \\
\hline Number of collections recorded & 7328 & 4511 & 36480 & 14627 \\
\hline Number of rams & 465 & 436 & 1880 & 974 \\
\hline $\begin{array}{l}\text { Average number of records } \\
\text { per animal (minimum-maximum) }\end{array}$ & $18(1-183)$ & $10(1-31)$ & $36(1-183)$ & $8(1-17)$ \\
\hline Number of sires & 111 & 131 & 230 & 197 \\
\hline $\begin{array}{l}\text { Number of animals in the final } \\
\text { pedigree file }\end{array}$ & & 96 & & \\
\hline
\end{tabular}

* Average (s.e.).

pool of 1 to 3 successive ejaculates, obtained over a $2-5$ min period, was evaluated immediately after collection. Three traits were evaluated for each pool: volume which was read directly from a graduated collection tube $(\mathrm{mL})$, semen concentration which was determined using a standard spectrophotometer $\left(10^{6}\right.$ spermatozoa per $\left.\mathrm{mL}\right)$ and mass motility which was assessed for undiluted unstained semen under a microscope. Mass motility was scored subjectively, on the basis of wave motion, on a 0 (no motion) to 5 (numerous rapid and vigorous waves) continuous scale.

\subsection{Models and methods}

Four dependent variables were analysed: the sperm concentration, ejaculate volume defined as the pool volume divided by the number of ejaculates, number of spermatozoa computed as the product of the ejaculate volume and sperm concentration and motility. Records above the threshold of $3 \mathrm{~mL}$ for the ejaculate volume, $8 \times 10^{6} \mathrm{spz} \cdot \mathrm{mL}^{-1}$ for concentration and 5 for motility were discarded; these represented 1 and $8 \%$ of the data in LAC and MTR rams, respectively. For motility, analysis was restricted to records above 4 because the scoring of a collection was not reliable below this threshold. Analysis was performed separately for each breed.

Six multiple trait animal models were considered for the estimation of the genetic parameters for semen production traits within breed. The first two models were multiple trait animal models (SAC model: single animal category) for semen traits in adult and young rams, respectively. The four other models (SSM model: single semen measurement) were multiple trait animal models 
for each semen trait of young and adult rams. Simple repeatability models were used for all traits in all multiple trait models. The random effects accounted for were the additive genetic effect, permanent environmental effect and residual. The fixed effects tested, using likelihood ratio tests, were season (week or midmonth), daily variation (AM/PM), age at collection in years (for adult rams only, age $=2-7,(7) \geqslant 7$ years), interval from previous collection in days (interval $=1-8 ;(8) \geqslant 8$ days), number of collections sustained the previous year (for adult rams only), rank of collection within season, breeding value for milk production in quartiles and all two-way interactions with biological meaning. For each model, variance and covariance components were estimated using a Restricted Maximum Likelihood method implemented in ASREML software [11] applied to multiple trait animal models. The heritability for each trait was estimated by $\hat{\sigma}_{a}^{2} / \hat{\sigma}_{T}^{2}$ with $\hat{\sigma}_{T}^{2}=\hat{\sigma}_{a}^{2}+\hat{\sigma}_{p}^{2}+\hat{\sigma}_{e}^{2}$ and where $\hat{\sigma}_{a}^{2}, \hat{\sigma}_{p}^{2}$ and $\hat{\sigma}_{e}^{2}$ are the variance estimates for additive genetic, random permanent environmental and random residual effects respectively for each trait. Repeatability was estimated by $\left(\hat{\sigma}_{a}^{2}+\hat{\sigma}_{p}^{2}\right) / \hat{\sigma}_{T}^{2}$.

\section{RESULTS}

\subsection{Analysis of fixed effects}

For the traits considered, the effects of the breeding value for milk production, the rank of collection within season, the number of collections sustained the previous year and all two-way interactions except season-year interaction were removed because they were not significant $(P>5 \%)$ in both breeds. The maximal variations due to the main fixed effects (in standard error unit) reaching significance for at least one trait are presented in Tables II and III for MTR and LAC rams, respectively.

The effects of year, season and the year-season interaction were significant for all traits in both breeds. The year of collection was one of the two principal causes of variation in both breeds and for all traits. A decrease of concentration with years was observed in both age categories and breeds, while for the other semen characteristics, there was no clear trend associated with year. The season effect was the principal cause of variation in nearly all cases. Volume, concentration and number of spermatozoa first increased and then decreased with season while no clear trend could be observed for motility.

In adult rams, the age effect was significant for concentration and number of spermatozoa in both breeds and for volume and motility in LAC rams only. All semen production traits tended to decrease for rams older than 3 years (Fig. 1). 
Table II. Maximum range between fixed effect estimates, in standard error unit, for each trait in Manech tête rousse rams.

\begin{tabular}{c|ccccccccc}
\hline & \multicolumn{2}{|c}{ Volume } & \multicolumn{3}{c}{ Concentration } & \multicolumn{2}{c}{ No. of } & \multicolumn{2}{c}{ Motility } \\
& Young & Adult & Young & Adult & Young & Adult & Young & Adult \\
\hline Year & 0.9 & 1.1 & 0.9 & 1.9 & 1.2 & 1.0 & 1.0 & 1.3 \\
Season & 1.0 & 1.9 & 1.2 & 1.4 & 1.1 & 1.3 & 0.7 & 0.5 \\
Interval with previous & 0.5 & 0.3 & $\#$ & 0.1 & 0.5 & 0.3 & 0.1 & 0.3 \\
collection & & & & & & & & \\
Number of ejaculates & 0.6 & 0.2 & 0.1 & 0.1 & 0.2 & 0.2 & $\#$ & 0.1 \\
Daily variation & 0.1 & $\#$ & $\#$ & $\#$ & $\#$ & $\#$ & 0.2 & 0.1 \\
Age & - & $\#$ & - & 2.9 & - & 1.0 & - & $\#$ \\
\hline
\end{tabular}

\#: Not significant effect; -: not tested.

Table III. Maximum range between fixed effect estimates, in standard error unit, for each trait in Lacaune rams.

\begin{tabular}{|c|c|c|c|c|c|c|c|c|}
\hline & \multicolumn{2}{|c|}{ Volume } & \multicolumn{2}{|c|}{ Concentration } & \multicolumn{2}{|c|}{$\begin{array}{c}\text { No. of } \\
\text { spermatozoa }\end{array}$} & \multicolumn{2}{|c|}{ Motility } \\
\hline & Young & Adult & Young & Adult & Young & Adult & Young & Adult \\
\hline Year & 0.5 & 2.2 & 1.4 & 1.9 & 0.5 & 0.8 & 0.5 & 0.9 \\
\hline Season & 1.0 & 0.8 & 1.1 & 1.2 & 0.6 & 0.4 & 0.4 & 0.6 \\
\hline $\begin{array}{l}\text { Interval with previous } \\
\text { collection }\end{array}$ & 0.2 & 0.4 & 0.2 & 0.3 & 0.3 & 0.6 & 0.2 & 0.2 \\
\hline $\begin{array}{l}\text { Number of } \\
\text { ejaculates }\end{array}$ & - & - & - & - & - & - & - & - \\
\hline Daily variation & 0.1 & 0.1 & 0.1 & 0.1 & 0.1 & 0.1 & 0.1 & 0.1 \\
\hline Age & - & 1.6 & - & 0.1 & - & 0.9 & - & 0.2 \\
\hline
\end{tabular}

-: Not tested.

The decrease in the number of spermatozoa with increasing age was very similar in both breeds. This was mainly due to a decrease of volume in LAC rams and a decrease of concentration in MTR rams.

Except for the concentration in young MTR rams, all traits were significantly affected by the interval with previous collection in both breeds. The same trend was observed for volume, number of spermatozoa and concentration (Fig. 2). They increased significantly from 0 (interval $=1$ ) to 2 (interval $=3$ ) days of abstinence, and remained stable (not significant differences) for the interval with previous collection higher than 3 days. Except for adult LAC rams, motility tended to decrease when the interval between collections increased from 1 to 4 days.

The daily variation significantly affected motility traits in both breeds (Tabs. II and III). Semen production traits were only significantly affected in 


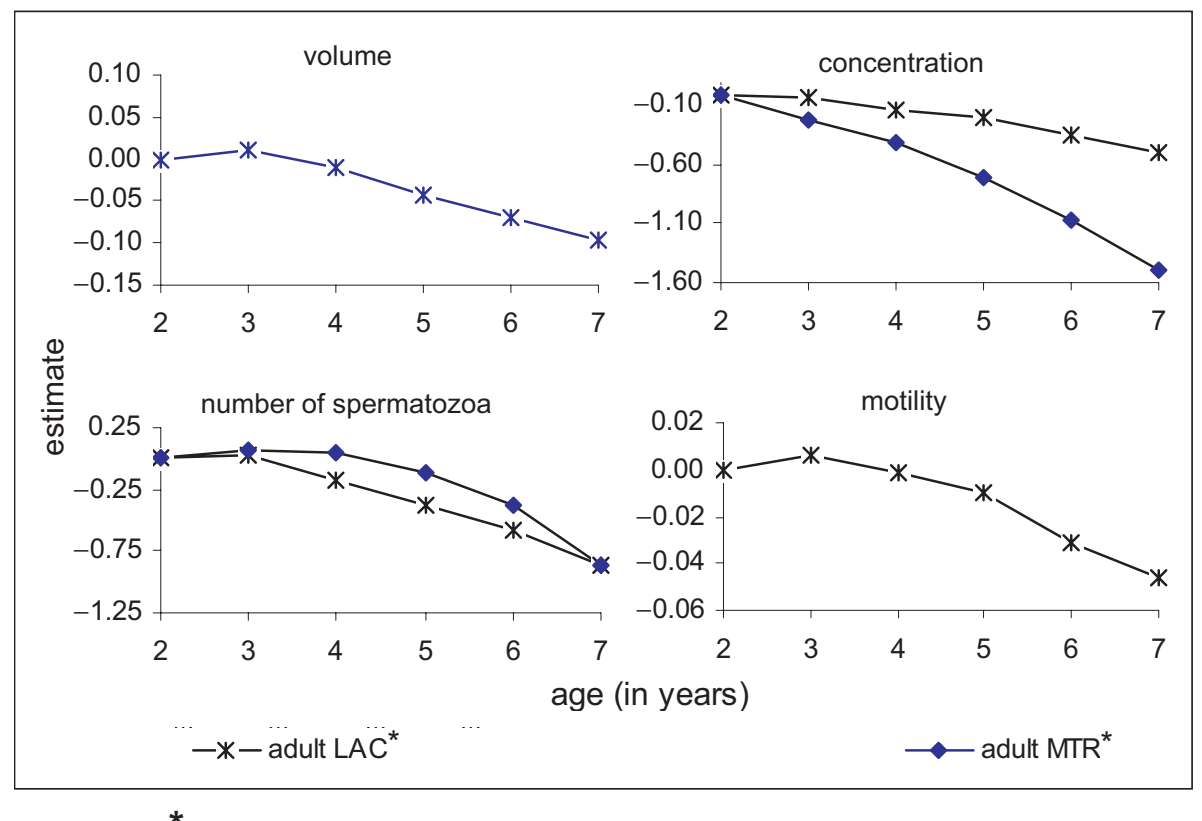

Figure 1. Effect of age on semen production.

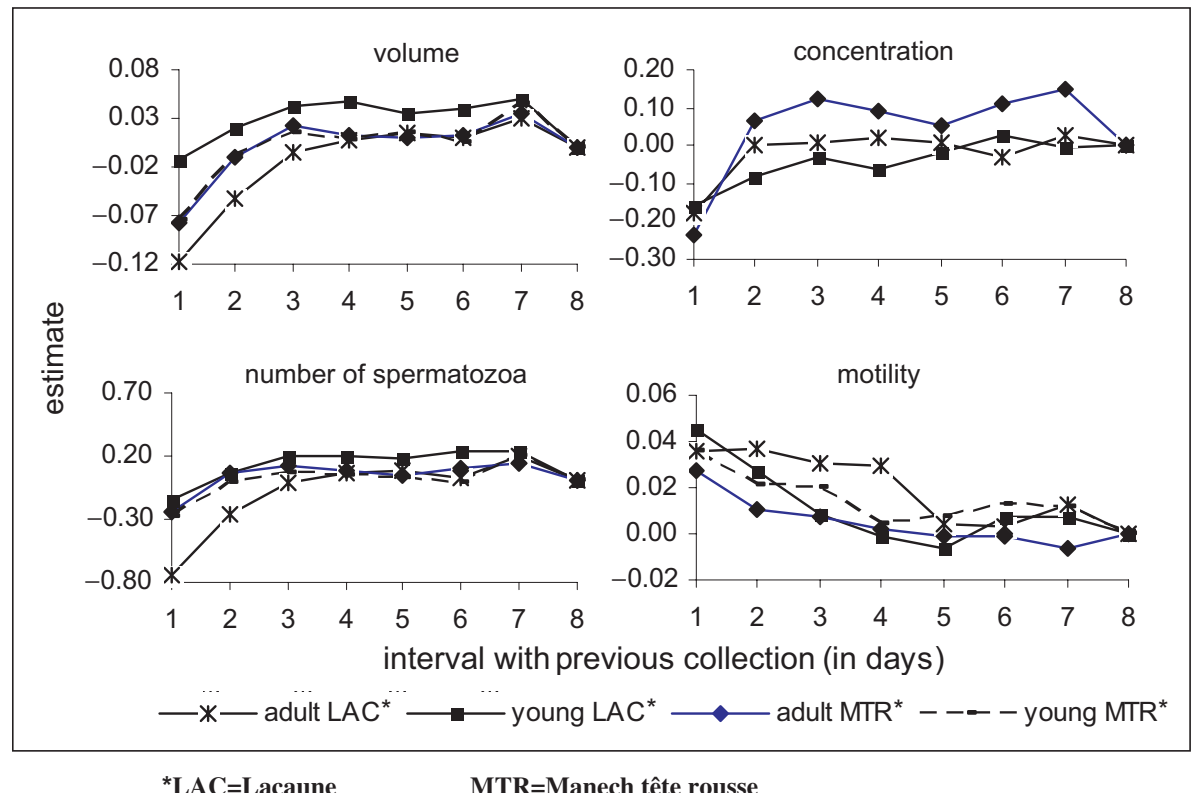

Figure 2. Effect of interval with previous collection on semen production. 
Table IV. Repeatability and standard error estimates obtained with the SAC ${ }^{\text {a }}$ model of semen characteristics in young and adult AI rams ${ }^{\mathrm{b}}$.

\begin{tabular}{|c|c|c|c|}
\hline & Traits & Young rams & Adult rams \\
\hline \multirow{4}{*}{$\begin{array}{l}\text { LAC } \\
\text { rams* }\end{array}$} & Volume & $0.35(0.01)$ & $0.46(0.01)$ \\
\hline & Concentration & $0.51(0.01)$ & $0.52(0.01)$ \\
\hline & Number of spermatozoa & $0.34(0.01)$ & $0.42(0.01)$ \\
\hline & Motility & $0.30(0.01)$ & $0.38(0.01)$ \\
\hline \multirow{4}{*}{$\begin{array}{l}\text { MTR } \\
\text { rams* }\end{array}$} & Volume & $0.39(0.02)$ & $0.47(0.02)$ \\
\hline & Concentration & $0.36(0.02)$ & $0.40(0.02)$ \\
\hline & Number of spermatozoa & $0.30(0.02)$ & $0.40(0.02)$ \\
\hline & Motility & $0.32(0.02)$ & $0.45(0.02)$ \\
\hline
\end{tabular}

${ }^{\text {a }}$ Model SAC $=$ multiple trait model within single animal category.

${ }^{\mathrm{b}}$ Standard error in brackets.

$*$ LAC $=$ Lacaune; MTR = Manech tête rousse.

LAC rams, except volume in young MTR rams. The same trend was observed for all traits: collections taken in the afternoon had better quality than those taken in the morning.

The effect of the number of ejaculations for a collection was studied only in MTR rams because this number was fixed to 2 in LAC rams. This effect significantly affected volume, concentration, and motility in both young and adult rams and the number of spermatozoa in adult rams only. Volume, concentration and number of spermatozoa decreased from 1 to 2 ejaculations while motility increased. There were no significant differences between 3 and 2 ejaculations for all traits.

\subsection{Repeatability and genetic parameters}

Repeatability estimates for each trait with the SAC model are presented in Table IV. The largest difference in repeatability estimates obtained with the SSM models never exceeded 0.01. Repeatabilities were moderate for most of the traits varying from 0.30 to 0.52 and were quite similar between breeds except for concentration. The estimates for adult rams tended to be higher than for young rams.

The estimates for heritability and correlations among traits are presented in Tables V and VI for young and adult rams, respectively. As for the repeatability, the differences in heritability estimates between the SAC and SSM models were small. The estimates were moderate for all traits, ranging from 0.12 to 0.33 , except for motility ranging from 0.02 to 0.14 . However, heritability 
Table V. Estimates of genetic parameters of semen characteristics in young AI rams ${ }^{\mathrm{a}}$.

\begin{tabular}{|c|c|c|c|c|c|c|}
\hline & Traits & Model $^{\mathrm{b}}$ & Volume & Concentration & $\begin{array}{c}\text { Number of } \\
\text { spermatozoa }\end{array}$ & Motility \\
\hline \multirow{4}{*}{$\begin{array}{l}\text { LAC } \\
\text { rams* }\end{array}$} & Volume & $\begin{array}{l}\text { SAC } \\
\text { SSM }\end{array}$ & $\begin{array}{l}\mathbf{0 . 1 8}(0.03) \\
\mathbf{0 . 1 9}(0.03)\end{array}$ & 0.13 & 0.89 & -0.03 \\
\hline & Concentration & $\begin{array}{l}\text { SAC } \\
\text { SSM }\end{array}$ & -0.24 & $\begin{array}{l}\mathbf{0 . 2 7}(0.04) \\
0.27(0.04)\end{array}$ & 0.52 & 0.20 \\
\hline & $\begin{array}{l}\text { Number of } \\
\text { spermatozoa }\end{array}$ & $\begin{array}{l}\text { SAC } \\
\text { SSM }\end{array}$ & 0.84 & 0.30 & $\begin{array}{l}\mathbf{0 . 1 7}(0.03) \\
\mathbf{0 . 1 7}(0.03)\end{array}$ & 0.05 \\
\hline & Motility & $\begin{array}{l}\text { SAC } \\
\text { SSM }\end{array}$ & -0.04 & 0.04 & -0.01 & $\begin{array}{l}\mathbf{0 . 0 7}(0.02) \\
\mathbf{0 . 0 7}(0.02)\end{array}$ \\
\hline \multirow{4}{*}{$\begin{array}{l}\text { MTR } \\
\text { rams* }\end{array}$} & Volume & $\begin{array}{l}\text { SAC } \\
\text { SSM }\end{array}$ & $\mathbf{0 . 3 3}(0.07)$ & 0.07 & 0.85 & -0.05 \\
\hline & Concentration & $\begin{array}{l}\text { SAC } \\
\text { SSM }\end{array}$ & -0.41 & $\begin{array}{l}\mathbf{0 . 1 8}(0.06) \\
\mathbf{0 . 2 0}(0.05)\end{array}$ & 0.53 & 0.23 \\
\hline & $\begin{array}{l}\text { Number of } \\
\text { spermatozoa }\end{array}$ & $\begin{array}{l}\text { SAC } \\
\text { SSM }\end{array}$ & 0.89 & -0.27 & $\begin{array}{l}\mathbf{0 . 1 9}(0.06) \\
\mathbf{0 . 1 8}(0.05)\end{array}$ & 0.07 \\
\hline & Motility & $\begin{array}{l}\text { SAC } \\
\text { SSM }\end{array}$ & -0.03 & 0.44 & -0.12 & $\begin{array}{l}\mathbf{0 . 1 4}(0.06) \\
\mathbf{0 . 1 1}(0.05)\end{array}$ \\
\hline
\end{tabular}

${ }^{\text {a }}$ Heritabilities (s.e.) on the diagonal, genetic and phenotypic correlations below and above the diagonal, respectively.

${ }^{\mathrm{b}}$ Model SAC $=$ multiple trait model within single animal category.

Model SSM = multiple trait model within semen measurement.

$*$ LAC $=$ Lacaune; MTR $=$ Manech tête rousse.

estimates differed between breeds. Heritabilities tended to be smaller in young LAC rams but higher in young MTR rams.

Phenotypic correlations among traits were similar in all groups (LAC, MTR, adult and young rams). The number of spermatozoa (product of volume and concentration) showed, as expected, a positive phenotypic correlation with volume and concentration, but the correlation was higher with volume. Small but positive (varying from 0.01 to 0.13 ) phenotypic correlations were observed between volume and concentration. Motility was slightly positively correlated with concentration ( 0.18 to 0.23$)$.

Genetic correlations among volume and other traits were similar in all groups. Volume was strongly positively correlated with number of spermatozoa (>0.84), moderately and negatively correlated with concentration $(-0.24$ to -0.53$)$ and only slightly negatively correlated with motility $(-0.03$ to -0.09). For other correlations, some differences between breeds were observed: concentration and number of spermatozoa were positively correlated in LAC rams (0.30: young, 0.20: adult) and negatively correlated in MTR rams (-0.27: young, -0.31 : adult). 
Table VI. Estimates of genetic parameters of semen characteristics in adult AI rams ${ }^{\mathrm{a}}$.

\begin{tabular}{|c|c|c|c|c|c|c|}
\hline & Traits & Model $^{b}$ & Volume & Concentration & $\begin{array}{c}\text { Number of } \\
\text { spermatozoa }\end{array}$ & Motility \\
\hline \multirow{4}{*}{$\begin{array}{l}\text { LAC } \\
\text { rams* }\end{array}$} & Volume & $\begin{array}{l}\text { SAC } \\
\text { SSM }\end{array}$ & $\begin{array}{l}\mathbf{0 . 2 6}(0.04) \\
\mathbf{0 . 2 7}(0.04)\end{array}$ & 0.04 & 0.86 & -0.02 \\
\hline & Concentration & $\begin{array}{l}\text { SAC } \\
\text { SSM }\end{array}$ & -0.33 & $\begin{array}{l}0.25(0.05) \\
0.27(0.05)\end{array}$ & 0.51 & 0.18 \\
\hline & $\begin{array}{l}\text { Number of } \\
\text { spermatozoa }\end{array}$ & $\begin{array}{l}\text { SAC } \\
\text { SSM }\end{array}$ & 0.85 & 0.20 & $\begin{array}{l}\mathbf{0 . 1 9}(0.04) \\
\mathbf{0 . 2 0}(0.04)\end{array}$ & 0.06 \\
\hline & Motility & $\begin{array}{l}\text { SAC } \\
\text { SSM }\end{array}$ & -0.08 & 0.07 & -0.04 & $\begin{array}{l}\mathbf{0 . 1 3}(0.03) \\
\mathbf{0 . 1 3}(0.03)\end{array}$ \\
\hline \multirow{4}{*}{$\begin{array}{l}\text { MTR } \\
\text { rams* }\end{array}$} & Volume & $\begin{array}{l}\text { SAC } \\
\text { SSM }\end{array}$ & $\begin{array}{l}\mathbf{0 . 2 5}(0.06) \\
\mathbf{0 . 3 0}(0.05)\end{array}$ & 0.01 & 0.86 & -0.08 \\
\hline & Concentration & $\begin{array}{l}\text { SAC } \\
\text { SSM }\end{array}$ & -0.53 & $\begin{array}{l}\mathbf{0 . 1 2}(0.05) \\
\mathbf{0 . 1 4}(0.05)\end{array}$ & 0.46 & 0.19 \\
\hline & $\begin{array}{l}\text { Number of } \\
\text { spermatozoa }\end{array}$ & $\begin{array}{l}\text { SAC } \\
\text { SSM }\end{array}$ & 0.89 & -0.31 & $\begin{array}{l}\mathbf{0 . 1 4}(0.06) \\
\mathbf{0 . 1 8}(0.05)\end{array}$ & 0.03 \\
\hline & Motility & $\begin{array}{l}\text { SAC } \\
\text { SSM }\end{array}$ & -0.09 & -0.70 & -0.74 & $\begin{array}{l}\mathbf{0 . 0 4}(0.04) \\
\mathbf{0 . 0 2}(0.04)\end{array}$ \\
\hline
\end{tabular}

${ }^{\text {a }}$ Heritabilities (s.e.) on the diagonal, genetic and phenotypic correlations below and above the diagonal, respectively.

${ }^{\mathrm{b}}$ Model SAC $=$ multiple trait model within single animal category.

Model SSM = multiple trait model within semen measurement.

$*$ LAC $=$ Lacaune; MTR $=$ Manech tête rousse.

The four different correlations calculated between traits recorded for young and adult rams are presented in Table VII. Genetic correlations between age categories for each trait differed from 1. Except for motility, correlations were higher in MTR than in LAC rams. Correlations between permanent environmental effects of young and adult rams were low in both breeds $(<0.5)$. Consequently, the correlations of ability to produce semen (genetic additive value + permanent environmental effect) between young and adult rams were moderate and ranged from 0.42 to 0.81 . In general, the correlations between adult ability and young genetic additive value were higher.

\section{DISCUSSION}

The present study has the advantage of analysing several years of semen production of rams with different ages, breeds, and locations. This gives the opportunity to identify similarities and differences in semen production among time, breeds or age. 
Table VII. Estimates of correlations of semen characteristics between young and adult AI rams with the $\mathrm{SSM}^{\mathrm{a}}$ model.

\begin{tabular}{|c|c|c|c|c|c|}
\hline & Traits & Corr $1^{b}$ & Corr $2^{b}$ & Corr $3^{b}$ & Corr $4^{b}$ \\
\hline \multirow{4}{*}{$\begin{array}{l}\text { LAC } \\
\text { rams* }\end{array}$} & Volume & 0.76 & 0.24 & 0.60 & 0.79 \\
\hline & Concentration & 0.51 & 0.38 & 0.50 & 0.54 \\
\hline & Number of spermatozoa & 0.52 & 0.33 & 0.50 & 0.56 \\
\hline & Motility & 0.81 & 0.41 & 0.62 & 0.76 \\
\hline \multirow{4}{*}{$\begin{array}{l}\text { MTR } \\
\text { rams* }\end{array}$} & Volume & 0.90 & 0.37 & 0.81 & 0.78 \\
\hline & Concentration & 0.89 & 0.27 & 0.53 & 0.60 \\
\hline & Number of spermatozoa & 0.81 & 0.16 & 0.42 & 0.59 \\
\hline & Motility & 0.14 & 0.48 & 0.58 & 0.00 \\
\hline
\end{tabular}

${ }^{\text {a }}$ Model SSM $=$ multiple trait model within semen measurement.

${ }^{\mathrm{b}}$ Corr $1=\operatorname{corr}($ va young, va adult);

Corr 2 = corr(ep young, ep adult);

Corr $3=\operatorname{corr}(e p+$ va young, ep + va adult $)$;

Corr 4 = corr(va young, ep + va adult);

where va $=$ additive genetic value, $\mathrm{ep}=$ permanent environmental effect.

$*$ LAC $=$ Lacaune; MTR $=$ Manech tête rousse.

The year effect which was encountered reflected a combination of an important list of factors which may affect semen production [10,18], some are not fully controllable by the AI centre (e.g. dryness, temperature, herd disease...) while others can be modified (e.g. nutrition, management, selection...). These factors were or could not be recorded and therefore have not been tested in the model. Explaining chaotic changes in volume and motility over the years is difficult. The decrease of the concentration may suggest a regular change of an environmental factor or an indirect response to selection on other traits. However, the same trends have been reported in humans even though they are partly controversial $[16,26]$.

The seasonal effect accounted for variations due to photoperiodic or melatonin treatments as described by Chemineau et al. [5] and Colas et al. [6] in adult rams. Sheep are short day breeders and these treatments are a substitute for decreasing day length allowing the obtention of, during the AI period, the same quantity and quality of semen as during the normal breeding season. Although breed, centre and seasonality treatment were confounded, melatonin implant tended to produce a shorter effect than photoperiodic treatment and was less repeatable in this study. More precisely, the season-year interaction corresponded mainly to quantitative interaction for photoperiodic treatment and qualitative interaction for melatonin implant. The seasonal variations of production traits tended to be less consistent for young than for adult rams. 
Indeed, for young rams the seasonal effect included daily gain which is known to affect semen traits $[19,20,23]$.

The age of rams affected the number of spermatozoa mainly due to effects on volume in LAC and concentration in MTR. This may be explained by a difference between AI centre management or between breed in the senescence of rams. The age effect on semen production has mainly been studied in young rams $(<2$ years) [22,23] but also in adults of other species [13, 25]. Since lifespan is different between species, a comparison between them has to be handled with care. In bulls, except for volume, a decrease of semen traits with age has also been reported $[10,13]$.

The same effect of daily variation has been reported by Duval et al. [8] and is explained by an increased libido of rams collected in the afternoon due to seeing other rams being collected in the morning. Nevertheless, the daily variation effect could also be the result of human behaviour.

The increase in volume and concentration with interval with previous collection is in accordance to earlier studies [9,20,21]. In practice, collecting rams every 3 rather than every 2 days will provide higher numbers of spermatozoa per ejaculate which would not compensate for the lower number of collections. As reported by Mathevon et al. [20], increasing the interval between collections led to a decrease of motility inducing lower fecundity. This question needs to be further investigated.

Concerning the effect of the number of ejaculations, similar results have been reported in the literature for quantitative traits (volume, concentration) $[9,15,21]$. For motility, the results diverged slightly. Ollero et al. [21] found a similar significant increase with ejaculate number in contrast to the results of Jennings and McWeeney [15], which could be due to the low reliability of motility measurement. The results shown for the effect of the number of ejaculations and the interval with previous collection could be related to senescence of spermatozoa due to the storage time in the tail of the epididymis and imbalance between spermatogenesis and ejaculation. In the present case, where rams had a moderate ejaculation frequency, a shorter interval between two collections led to higher motility and a lower number of spermatozoa. Consequently, there could be an optimum interval which ensures the higher quantity of highly motile spermatozoa.

The repeatability of adult rams tended to be higher than that of young rams. Adults presented a more stabilised semen production perhaps because they had reached puberty for a longer time and they got used to collection in the present management conditions. A similar difference between young and adult rams has been reported by Duval et al. [8] for volume and number of spermatozoa 
and by Mathevon et al. [20] for all traits. Repeatabilities were in the middle of the range of estimates in previous studies. Values from 0.27 (in pigs) to 0.71 (in bucks) for the volume [3,19], from 0.31 (in boars) to 0.70 (in bucks) for the concentration, from 0.20 (in rams) to 0.65 (in bucks) for the number of spermatozoa $[8,19]$ and from 0.15 (in rams) to 0.64 (in bulls) for the motility $[8,20]$ were reported. This wide range may be explained by the variety of species and the large number of categories of animals involved in these studies (breed, age).

The differences in heritability between breeds are common to other results in the literature [3,19]. Similar to the tendency in LAC rams, Duval et al. [8] and Mathevon et al. [20] observed a smaller heritability in young than in adult animals. This trend was not observed in MTR rams. Indeed, in this breed, semen is only collected from young rams having sufficiently "good" semen characteristics during their first year of life while in LAC, semen is collected from all rams that are able to serve into the artificial vagina. The results obtained were in the middle of the range of heritability estimated in previous studies on different species: from 0.11 (in rams) to 0.65 (in bulls) for volume [14,22], from 0.06 (in rams) to 0.49 (in boars) for concentration [8,24], from 0.06 (in rams) to 0.63 (in boars) for the number of spermatozoa $[8,24]$ and from 0.01 (in bulls) to 0.42 (in boars) for motility [20,24]. This variability in the literature results probably has a similar explanation to that mentioned before for repeatability. Moreover, in some studies [14,24], the results were obtained using the average of ejaculates which yielded higher heritability estimates.

Phenotypic and genetic correlations between volume, concentration and number of spermatozoa were in accordance with those found in the literature $[1,22,24]$. Genetic correlations between number of spermatozoa and concentration were opposed in LAC and in MTR. This result is not independent of the relationship between volume and these two traits: number of spermatozoa $=$ volume $\times$ concentration. In fact, volume and number of spermatozoa were highly positively correlated and volume and concentration were negatively correlated in both breeds but much more negative in MTR than in LAC. The variability in genetic correlation estimates between motility and other traits may be explained by the subjectivity and lack of reliability of this trait. We found that semen traits were genetically different between young and adult rams. In our analysis, young rams were still growing which is known to have an effect on semen characteristics $[13,19,20,23]$. The lack of information on daily gain in our data led us to consider that genes affecting growth may also be affecting semen production. This might also explain the differences in heritability estimates between young and adult rams. If available, individual body 
growth could be taken into account as a covariate trait in a structural model which would provide better estimates of genetic parameters of semen production traits.

\section{CONCLUSION}

In the present study, environmental factors identified as affecting semen production showed, in general, the same trend for all categories of animals and breeds. The analysis of these environmental factors may help AI centres to improve semen production even if the effect of year needs more investigation.

Heritabilities of semen production traits were moderate and could respond to selection. Theoretically, ejaculate volume would be the most interesting trait to consider because it has the highest heritability and is strongly positively correlated with the number of spermatozoa and slightly negatively correlated with motility. In practice, AI centres are at the present time interested in having objective values of semen production (additive genetic and "ability" values) to improve the choice of selected adult rams.

Nevertheless, the impact of semen trait selection on other traits (e.g. fertility, prolificacy, dairy traits, adult body size) must be evaluated beforehand.

\section{ACKNOWLEDGEMENTS}

The authors thank the ministère de l'Agriculture for supporting this study in the frame of a "BELIA action", directed by the ANIO and the INRA, and the $\mathrm{AI}$ centres who provided the data: $\mathrm{BMC}, \mathrm{CCDEO}$, Confédération générale de Roquefort, Insem-Ovin, OVI-TEST, CIA Verdilly.

The authors are also grateful to the anonymous referees for their valuable comments which helped to improve the manuscript.

\section{REFERENCES}

[1] Basso B., Fritz S., Druet T., Guillaume F., Rossignil M.N., Amigues Y., Gabriel R., Sellem E., Salas-Cortes L., Humblot P., Druart X., Estimation de paramètres génétiques et détection de QTL liés à des caractères de fertilité mâle, de production de semence et de qualité de la semence chez le taureau laitier, in: Rencontre Recherche Ruminants, 7-8 December 2005, Paris, pp. 145-148.

[2] Boland M.P., Al-Kamali A.A., Crosby T.F., Haynes N.B., Howles C.M., Kelleher D.L., Gordon I., The influence of breed, season and photoperiod on semen characteristics, testicular size, libido and plasma hormone concentrations in rams, Anim. Reprod. Sci. 9 (1985) 241-252. 
[3] Brandt H., Grandjot G., Genetic and environmental effects of male fertility of AI-boars, in: 6th World Congress on Genetics Applied to Livestock Production, 11-16 January 1998, Armidale, pp. 527-530.

[4] Brown B.W., A review of nutritional influences on reproduction in boars, bulls and rams, Reprod. Nutr. Dev. 34 (1994) 89-114.

[5] Chemineau P., Malpaux B., Pelletiet J., Leboeuf B., Delgadillo J.A., Deletang F., Pobel T., Brice G., Emploi des implants de mélatonine et des traitements photopériodiques pour maîtriser la reproduction saisonnière chez les ovins et les caprins, INRA Prod. Anim. 9 (1996) 45-60.

[6] Colas G., Guerin Y., Clanet V., Solari A., Influence of the photoperiod on the production and fecundity of spermatozoa in the adult Ile-de-France ram, Reprod. Nutr. Dev. 25 (1985) 101-111.

[7] David I., Bodin L. Lagriffoul G., Manfredi E., Robert-Granié C., Character process model for semen volume in AI rams: evaluation of correlation structures for long and short-term environmental effects, Genet. Sel. Evol. 39 (2007) 55-71.

[8] Duval P., Belloc J.P., Albaret M., Girou P., Barillet F., Étude de facteurs de variation de la fonction sexuelle de béliers Lacaune lait et de la fertilité des brebis en insémination artificielle, in: Rencontre Recherche Ruminant, 13-14 December 1995, Paris, pp. 429-434.

[9] Everett R.W., Bean B., Foote R.H., Sources of variation of semen output, J. Dairy Sci. 61 (1978) 90-95.

[10] Fuerst-Waltl B., Schwarzenbacher H., Perner C., Sölkner J., Effects of age and environmental factors on semen production and semen quality of Austrian Simmental bulls, Anim. Reprod. Sci. 95 (2006) 27-37.

[11] Gilmour A.R., Gogel B.J., Cullis B.R., Welham S.J., Thompson R., ASReml User Guide Release 1.0, Ltd V.I., Editor, 2002.

[12] Gundogan M., Demirci E., Monthly changes in some reproductive parameters and in testosterone and thyroxine values of rams throughout one year under continental climate conditions, Dtsch. Tierarztl. Wochenschr. 110 (2003) 450-453.

[13] Hahn J., Foote R.H., Seidel G.E. Jr., Testicular growth and related sperm output in dairy bulls, J. Anim. Sci. 29 (1969) 41-47.

[14] Humblot P., Bianchi M., Mechekour F., Nibart M., Thibier M., Effets respectifs du taureau sur les taux de non fécondation et de mortalité embryonnaire précoce après superovulation, EL et Ins. 211 (1986) 15-25.

[15] Jennings J.J., McWeeney J., Effect of frequent ejaculation on semen characteristics in rams, Vet. Rec. 98 (1976) 230-233.

[16] Jouannet P., Wang C., Eustache F., Kold-Jensen T., Auger J., Semen quality and male reproductive health: the controversy about human sperm concentration decline, Apmis. 109 (2001) 333-344.

[17] Kendall N.R., McMullen S., Green A., Rodway R.G., The effect of a zinc, cobalt and selenium soluble glass bolus on trace element status and semen quality of ram lambs, Anim. Reprod. Sci. 62 (2000) 277-283.

[18] Kunavongkrit A., Suriyasomboon A., Lundeheim N., Heard T.W., Einarsson S., Management and sperm production of boars under differing environmental conditions, Theriogenology 63 (2005) 657-667. 
[19] Manfredi E., Leboeuf B., Bodin L., Boue P., Humblot P., Source de variations génétiques et non génétiques des caractéristiques de production de semence chez le bouc, in: Rencontre Recherche Ruminant, 2-3 December 1998, pp. 37-39.

[20] Mathevon M., Buhr M.M., Dekkers J.C., Environmental, management, and genetic factors affecting semen production in Holstein bulls, J. Dairy Sci. 81 (1998) 3321-3330.

[21] Ollero M., Muino-Blanco T., Lopez-Perez M.J., Cebrian-Perez J.A., Viability of ram spermatozoa in relation to the abstinence period and successive ejaculations, Int. J. Androl. 19 (1996) 287-292.

[22] Rege J.E., Toe F., Mukasa-Mugerwa E., Tembely S., Anindo D., Baker R.L., Lahlou-Kassi A., Reproductive characteristics of Ethiopian highland sheep. II. Genetic parameters of semen characteristics and their relationships with testicular measurements in ram lambs, Small Rumin. Res. 37 (2000) 173-187.

[23] Salhab S.A., Zarkawi M., Wardeh M.F., Al-Masri M.R., Kassem R., Characterization and evaluation of semen in growing Awassi ram lambs, Trop. Anim. Health Prod. 35 (2003) 455-463.

[24] Smital J., Wolf J., De Sousa L.L., Estimation of genetic parameters of semen characteristics and reproductive traits in AI boars, Anim. Reprod. Sci. 86 (2005) $119-130$.

[25] Willett E.L., Ohms J.I., Measurement of testicular size and its relation to production of spermatozoa by bulls, J. Dairy Sci. 40 (1957) 1559-1569.

[26] Zhang S.C., Wang H.Y., Wang J.D., Analysis of change in sperm quality of Chinese fertile men during 1981-1996, Shengzhi Yu Biyun. 10 (1999) 33-39. 